\title{
THE MACROECONOMIC DETERMINANTS OF CROSS-COUNTRY FDI FLOWS: A COMPARATIVE ANALYSIS THROUGH THE DRISCOLL- KRAAY, 2SLS AND GMM MODELS
}

\author{
Sujan Chandra Paul ${ }^{1+}$ \\ Sujan Chandra Paul
Md Harun Or Rosid \\ Zhao Xuefeng ${ }^{3}$ \\ Mohammad Rakibul \\ Islam $^{4}$
}

\author{
${ }^{1,4}$ Department of Accounting $\&$ Information Systems, University of Barishal, \\ Bangladesh. \\ 'Email:sujan9099@gmail.com \\ ${ }^{2, s}$ School of Management, Huazhong University of Science and Technology \\ (HUST), Wuhan, PRC
}

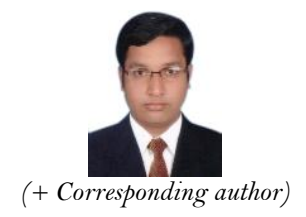

(+ Corresponding author

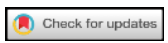

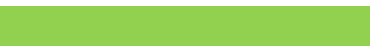

Article History

Received: 7 October 2020 Revised: 11 January 2021 Accepted: 3 February 2021 Published: 22 February 2021

\section{Keywords}

Foreign direct investment Gross domestic product Gross capital formation Agriculture

Forestry

Fishing

Industry

Export

Import

Inflation rate

Unemployment rate.

\section{JEL Classification:} E10, E20, F41.

\section{ABSTRACT}

This study investigates the relationship of foreign direct investment (FDI) with major macroeconomic variables, explicitly gross domestic product (GDP), gross capital formation (GCF), agriculture, forestry and fishing (AFF), industry, import, export, inflation, and unemployment rate. Panel data from 205 countries from 1990 to 2018 were collected from the website of the World Bank. Robustness of the result has been ensured through the combined use of ordinary least squares (OLS), pooled ordinary least squares (POLS), Driscoll-Kraay (DK), two-stage least squares (2SLS) and generalized method of moments (GMM) models. This research has found that GDP and GCF had a significant positive relationship with FDI across all the models, while $\mathrm{AFF}$ and the unemployment rate had a significant negative and positive relationship with FDI in all models except the GMM model. Industry and import had a significant positive relationship with FDI in the POLS model, and export and inflation had no significant relationship with FDI in any model.

Contribution/Originality: This study contributes to the existing literature through a utilitarian way to investigate the relationship of FDI with major macroeconomic variables globally.

\section{INTRODUCTION}

This paper analyzed the relationship between foreign direct investment (FDI) and macroeconomic variables including gross domestic product, gross capital formation, value addition of agriculture, forestry and fishing, value addition of industry including constructions, import of goods and services, export of goods and services, consumer price indices and unemployment rate. It is thought that there might be a link between foreign direct investments and these variables as all of these indicators, directly and indirectly, influence the gross domestic product of a country.

Shiva and Agapi (2008) said foreign direct investment and trade are also seen as significant catalysts for developed countries' economic development. They introduced FDI as an important tool for the transition of technology from developed to emerging countries. Kueh, Puah, and Abu Mansor (2009) claimed that Malaysia's 
external FDI data was particularly apparent in the 1990s. Their research aimed to investigate the macroeconomic determinants of Malaysia's outer FDI, namely real wages, exchange rate, free trade and interest rate. They used the cointegration test by Johansen and Juselius and the vector error correction technique. They studied the quarterly data from Q1 1991 to Q4 2005 and found that Malaysia 's outward FDI is favorably influenced in the long run by all of the variables under review. They also found that in the short term, Granger's interest rate will not trigger external FDI.

Babajide and Lawal (2016) analyzed the interaction between FDI and some of the chosen macroeconomic factors in both Nigeria's long-term and short-term equilibrium based on FDI macroeconomic theory. Their research used ARDL estimation techniques to investigate whether the chosen macroeconomic variables have a substantial impact on FDI, what macroeconomic variable(s) should be exploited to boost FDI inflows to the economy of the country and what policies should be implemented. They found that strategies that aim to boost trade, raise government spending, control the exchange rate mechanism, reduce inflation and interest rates are useful to draw FDI inflows.

Iwasaki and Tokunaga (2014) published a meta-analysis of the literature that empirically analyzed the effect of FDI on economic development in Central and Eastern Europe and the former Soviet Union. The findings of their analysis of meta-regression revealed that the impact size and statistical importance of the recorded effects are highly dependent on the conditions of the study. They found that current studies indicate a growth-enhancing impact of FDI in the entire region. They also noted that the experiments in question did not provide conclusive evidence of a non-zero FDI influence. Ultimately, they claimed that further work was required to determine the true effect.

The paper is divided into five chapters; the first chapter is the introduction, the second chapter is aimed at the relevant literature overview, models used and data are specified in the third chapter, which also deals with research methodology, the fourth chapter is about the findings and analysis of the different models, and the last chapter includes a conclusion along with some recommendations.

\section{LITERATURE REVIEW}

Many scholars have confirmed the positive effect of FDI on developing economies (Carkovic \& Levine, 2002; Garibaldi, Mora, \& Sahay, 2002; Neuhaus, 2006). FDI is especially important for transition economies, as these economies have inadequate savings, and technologies and resources are required to support economic development. (Bevan \& Estrin, 2000; Billington, 1999).

De Mello has noticed a beneficial impact of FDI on economic development, both in developed and developing countries, but concludes that long-term growth in host countries is driven by technology and infrastructure. Information spillovers from countries that spend in developing countries (De Mello, 1999). Blomstrom states that for FDI to have a significant effect on economic growth, the nation must have reached a degree of production that allows it to benefit from the effects of high productivity (Blomstrom, Lipsey, \& Zejan, 1994).

Through a cross-country regression method, Borensztein, De Gregorio, and Lee (1998) examined the effect of foreign direct investment (FDI) on economic development using data on FDI flows from developed countries to 69 developing countries over the past two decades. Their results indicate that FDI has become a significant tool for technology transition, contributing comparatively more to growth than domestic investment.

Schneider and Frey (1985) clarified that four formulas are econometrically measured and compared by ex-post projections to the distribution of foreign direct investment in 80 of the least developed countries. A politicoeconomic model that combines economic and political determinants at the same time works better. The higher the real per capita GNP, and the lower the balance of payments gap, the more they attract foreign direct investment. The amount of bilateral assistance coming from western countries and multilateral assistance has a positive impact among the political determinants, while the aid from communist countries has a negative effect. Economic uncertainty lowers the foreign direct investment inflows substantially. 
Theodore Moran (2012) claimed that foreign direct investment (FDI) existed when a corporation in one country established a business operation in another country by creating a new wholly-owned subsidiary, purchasing a local enterprise, or forming a host economy joint venture. International direct investment flows to emerging countries took at least four distinct forms: extractive-industry FDI; transportation FDI; production and assembly FDI; and services FDI. Each had distinctive commitments to bring to the development and wellbeing of host countries and each presented distinctive hazards or adverse risks to the development and health of host countries (Moran, 2012).

According to Markusen and Venables (1999), an FDI initiative impacts local businesses in the same market. They said competition on the commodity and factor markets appeared to decrease local firms' profits, but linking effects to supplier industries could minimize input costs and raise profits. Additionally, they developed an empirical method for assessing these results. Circumstances have been developed in which FDI complements local industry, and it has been shown how FDI could contribute to the development of local industrial sectors. These industries may expand to the point that local development overtakes FDI plants and drives them out.

James (2008) analyzed Malaysia's FDI determinants for informing theoretical and policy discussions using annual time series data from 1960 to 2005. Consistent with the market size hypothesis forecast, his analysis shows that actual GDP has a major positive effect on the FDI inflows. There has been evidence that the GDP growth rate has a tiny positive effect on incoming FDI. From a policy point of view, the findings indicated that the degree of financial growth, infrastructure creation and trade flexibility should be increased to encourage FDI. In comparison, a higher statutory corporate tax rate and the actual exchange rate tended to deter FDI inflows. Ironically, the findings do seem to indicate that enhanced macroeconomic volatility causes further inflows of FDI

Bekhet and Al-Smadi (2015) measured FDI from 1978 to 2012 and the long-term and short-term relationships between FDI inflows and their determinants in Jordan. Using the boundary testing method, they evaluated the long-run and short-run relationships between variables. They also used the Granger causality test that was used to investigate the causality paths between variables. Their findings established that FDI and its determinants had long-run and short-run relationships. Finally, the Jordanian decision makers were advised to be informed of the importance of incoming FDI in the Jordanian economy. Shiva and Agapi (2008) said foreign direct investment and trade are also seen as significant catalysts for developed countries ' economic development. They introduced FDI as an important tool for the transition of technology from developed to emerging countries. In addition, FDI promotes domestic investment and encourages developments in the host country's human resources and institutions (Bekhet \& Al-Smadi, 2015).

Boateng, Hua, Nisar, and Wu (2015) looked at the location-specific benefit of the effect of macroeconomic factors on FDI inflows in Norway. They used quarterly data to cointegrate regressions with a fully modified OLS (FMOLS) and the vector autoregressive and error correction models (VAR/VECM). Their study found that real GDP, GDP sector, exchange rate and trade openness had a positive and significant impact on FDI inflow. Money supply, inflation, unemployment and interest rate, however, generated considerably negative effects. Their findings suggested that in trying to cultivate diverse competitive in the home market, policymakers need to pay more attention to their macroeconomic policies to support the design and reduce the cost of multinational enterprises (MNEs) for output and transactions. Tolentino (2010) analyzed the relationships between a few home countryspecific macroeconomic variables, and China and India external FDI flows using various time-series data from 1982 to 2006 and 1980 to 2006, respectively. Their emphasis was on analyzing the Granger causal relationships by exogeneity analysis as well as assessing the short-term functional relationships between external FDI flows and other function variables using autoregressive vector modeling. Researchers concluded that while China and India hold similar inferences about the Granger causal relationships involving external FDI flows, both countries differed in deciding the endogenous structure and dynamics of the multiple time series. Alguacil, Cuadros, and Orts (2011) added to the debate on the role of absorptive power within host economies in its ability to expand and effectively 
leverage FDI. Their findings for a comparison of emerging economies during the 1976-2005 period indicate variations related to both the estimation process (the program GMM vs OLS method) and the extent of economic growth. They also outlined the value of managing the macroeconomic and structural climate for those local capacities. They suggested that a series of policies be created for the host country governments that concentrate not just on supporting inward FDI but also on strengthening their political and economic structures (Alguacil et al., 2011). Li and Liu (2005) analyzed how foreign direct investment influences economic growth and focused on a data panel for 84 countries from 1970 to 1999. This interaction was investigated using both single equation and simultaneous equation method techniques. Since the mid-1980s a significant endogenous association between FDI and economic growth has been established. In addition to directly promoting economic growth on its own, FDI does so indirectly via its terms of interaction. FDI's engagement with human resources has a significant positive influence on developed countries ' economic development, while its involvement with the infrastructure deficit has a significant negative impact.

Reiter and Steensma (2010) noted that while policymakers attach great importance to foreign direct investment in promoting growth in developed countries, the ties between FDI, economic development and human development remain tenuous. They seek to explain these relationships in greater detail by exploring the effect of FDI policy and corruption on those relationships. They found that FDI inflows are more closely linked to human development growth when FDI policy prevents foreign investors from accessing those economic sectors and when it discriminates against international investors compared with domestic investors. FDI's connection to human development progress is even more highly favorable when corruption is weak.

Alfaro, Chanda, Kalemli-Ozcan, and Sayek (2004) looked at the different linkages between FDI, capital markets and economic development. We explored whether countries with better financial systems can more effectively exploit FDI. Empirical analysis, using cross-country data from 1975 to 1995, shows that the role of FDI alone in contributing to economic growth is ambiguous. However, FDI benefits substantially from countries with welldeveloped capital markets. The findings are robust for numerous initiatives to improve the stock system, among other determinants of Economic growth, and an endogenous consideration.

FDI impacts the export output of the host country, the spillover effects of which are referred to as indirect effects (Banga, 2006). Studies performed in China showed that increased levels of FDI had a positive effect on Chinese manufacturing export output (Sun, 2001; Zhang \& Song, 2001; Zhang, 2005). However, this success is since FDI has primarily been export-oriented in China, and related observations have been found in Ireland by Barry and Bradley (1997). Research by Aggarwal (2002) analyzed the relationship between FDI and export output using the tobit model for the period from 1996 to 2000 and found that the liberalized system improved the export position of international affiliates. Sharma (2000) analyzed the determinants of export growth and concluded that although the impact of FDI on export supplies is positive, it is not important. Miankhel, Thangavelu, and Kalirajan (2009) found that export development induced FDI in Pakistan, Malaysia and Mexico, and Pradhan (2010) observed that exchange openness is the source of FDI inflows.

\section{METHODOLOGY}

The explorative analysis was carried out according to the following data and methods:

\subsection{Data}

Secondary dynamic panel data was collected for 205 countries around the world between 1990 and 2018 , mainly from World Development Indicators of the World Bank. The data comprises 205 countries, 29 years and nine variables. As the data were presented in different units of currency and figures, data correction was done to harmonize the data for cross-analysis. Initially, it was log normalized to analyze the stochastic frontier, then the data was first degree differentiated to neutralize the autocorrelation problem. Some data were in million dollar 
figures, some were in billion dollar figures, some were in local currencies, some were in percentiles and some were in ratios. All these data were converted into billion dollars for all the variables.

\subsection{Methods}

A composite step-by-step model-based study was conducted.

i) Ordinary least squares (OLS): The OLS model was used to define the relationship between FDI and macroeconomic variables.

ii) Pooled ordinary least squares (POLS): The POLS model was used to identify the relationship between FDI and macroeconomic variables, which boosts the findings of OLS.

iii) Driscoll-Kraay (DK): The DK model was used to identify the relationship between FDI and macroeconomic variables to ensure primary robustness of the model.

iv) Two-stage least squares model $(2 S L S)$ : The 2 SLS was also used to ensure added robustness in finding the relationship between FDI and macroeconomic variables.

v) Generalized method of moments (GMM): The GMM model was used to identify significant explanatory variables that can explain the relationship between FDI and macroeconomic variables with the utmost robustness.

\subsection{Variables and Description}

Table 1 summarizes the list of variables found and used in the study as per existing literature.

Table 1. Variables and Constructs

\begin{tabular}{c|c|lc}
\hline Sl.no. & Variable & Description & Unit \\
\hline 1 & $\operatorname{lnFDI}$ & $\begin{array}{l}\text { Log normal of foreign direct investment, net inflows (Balance of Payment, } \\
\text { current) }\end{array}$ & USD \\
\hline 2 & $\ln$ GDP & Log normal of gross domestic product (current) & USD \\
\hline 3 & $\ln$ GCF & Log normal of gross capital formation & \% of GDP \\
\hline 4 & $\ln$ AFFva & Log normal of agriculture, forestry, and fishing, value added & \% of GDP \\
\hline 5 & $\operatorname{lnInva}$ & Log normal of industry (including construction), value added & \% of GDP \\
\hline 6 & $\operatorname{lnIM}$ & Log normal of imports of goods and services & \% of GDP \\
\hline 7 & $\operatorname{lnEx}$ & Log normal of exports of goods and services & \% \\
\hline 8 & $\operatorname{lnINF}$ & Log normal of inflation, consumer prices (annual) & labor total force) \\
\hline 9 & $\ln$ UNEM & Log normal of unemployment, total (modeled ILO estimate) & \\
\hline
\end{tabular}

\subsection{Hypotheses}

Table 2 summarizes the list of hypotheses developed and tested in the study as per literature.

Table 2. List of Hypotheses

\begin{tabular}{c|l}
\hline No. & Hypotheses \\
\hline $\mathrm{H}_{1}$ & There is a significant positive relationship between foreign direct investment and gross domestic product. \\
\hline $\mathrm{H}_{2}$ & There is a significant positive relationship between foreign direct investment and gross capital formation. \\
\hline $\mathrm{H}_{3}$ & $\begin{array}{l}\text { There is a significant positive relationship between foreign direct investment and agriculture, forestry and } \\
\text { fishing, value added. }\end{array}$ \\
\hline $\mathrm{H}_{4}$ & $\begin{array}{l}\text { There is a significant positive relationship between foreign direct investment and industry, value added. } \\
\mathrm{H}_{5}\end{array}$ \\
\hline $\mathrm{H}_{6}$ & $\begin{array}{l}\text { There is a significant negative relationship between foreign direct investment and imports of goods and } \\
\text { services. }\end{array}$ \\
\hline $\mathrm{H}_{7}$ & $\begin{array}{l}\text { There is a significant positive relationship between foreign direct investment and exports of goods and } \\
\text { services. }\end{array}$ \\
\hline $\mathrm{H}_{8}$ & $\begin{array}{l}\text { There is a significant negative relationship between foreign direct investment and inflation, consumer } \\
\text { prices. }\end{array}$ \\
\hline
\end{tabular}




\section{FINDINGS AND RESULTS}

A summary of the descriptive statistics of all the variables used in the models of this study is given below. The table includes the number of observations, mean scores, standard deviations and the minimum and maximum scores for each variable.

Table 3. Descriptive Statistics.

\begin{tabular}{c|c|c|c|c|c}
\hline Variable & Obs. & Mean & Std. Dev. & Min. & Max. \\
\hline FDI & 5511 & $8.60 \mathrm{e}+09$ & $3.70 \mathrm{e}+10$ & $-2.39 \mathrm{e}+11$ & $7.34 \mathrm{e}+11$ \\
\hline GDP & 5612 & $3.35 \mathrm{e}+11$ & $1.53 \mathrm{e}+12$ & 8820000 & $2.23 \mathrm{e}+13$ \\
\hline GCF & 4825 & 23.52 & 8.29 & -2.424 & 85.101 \\
\hline AFFva & 5200 & 13.199 & 12.546 & .025 & 79.042 \\
\hline Inva & 5182 & 26.768 & 12.317 & 2.073 & 87.797 \\
\hline IM & 5173 & 46.197 & 26.634 & 0 & 236.391 \\
\hline EX & 5173 & 39.576 & 27.605 & .005 & 228.994 \\
\hline INF & 5547 & 35.436 & 472.106 & -31.566 & 26765.86 \\
\hline UNEM & 5228 & 8.061 & 6.165 & .11 & 37.976 \\
\hline
\end{tabular}

Table 3 shows a summary of the data collected for 205 countries over 29 years on nine variables. The main dependent variable, FDI, shows an average of 8.60 billion USD for the countries studied along with a very high standard deviation of 3.70 billion USD, which indicates there is considerable disparity in FDI among the countries of the world. This table also shows that the gross domestic product average is 3.35 and the standard deviation is 1.53, while the gross capital formation average is 23.52 and the standard deviation is 8.29. The mean of agriculture, forestry and fishing value added is 13.199 percent, whereas the mean of industry value added is 26.768 percent with 12.54 percent and 12.31 percent standard deviations. The mean import of goods and services is 46.197 percent of GDP with 26.63 percent standard deviation, whereas the mean of export of goods and services is 39.57 percent of GDP with 27.60 percent standard deviations. Average inflation is 35.43 with a very low standard deviation of 472.10 , while unemployment has a mean score of 8.06 with a standard deviation of 6.16 . So, a thorough study to understand the disparity among these countries is undoubtedly necessary. The current study attempted to do so within the limits of the scope.

\subsection{Pairwise Correlation Matrix}

To identify the impact of democracy indices on FDI, first, we analyzed the correlations among the variables obtained from the literature. A combined correlation matrix is given below to report the variables.

Table 4. Pairwise Correlations Matrix.

\begin{tabular}{|c|c|c|c|c|c|c|c|c|c|}
\hline Variables & (1) & $(2)$ & (3) & $(4)$ & $(5)$ & (6) & $(7)$ & $(8)$ & (9) \\
\hline (1) $\ln \mathrm{FDI}$ & \multicolumn{2}{|l|}{1.000} & & & & & & & \\
\hline (2) $\ln \mathrm{GDP}$ & $0.346^{*}$ & 1.000 & & & & & & & \\
\hline (3) $\ln \mathrm{GCF}$ & $0.297^{*}$ & $0.579^{*}$ & 1.000 & & & & & & \\
\hline (4) $\ln \mathrm{AFF}_{\mathrm{Va}}$ & $0.021^{*}$ & $0.127^{*}$ & $0.189^{*}$ & 1.000 & & & & & \\
\hline (5) lnInva & $0.221^{*}$ & $0.566^{*}$ & $0.474^{*}$ & $0.387^{*}$ & 1.000 & & & & \\
\hline (6) $\ln \mathrm{IM}$ & $0.239^{*}$ & $0.508^{*}$ & $0.685^{*}$ & $0.163^{*}$ & $0.400^{*}$ & 1.000 & & & \\
\hline (7) $\ln \mathrm{EX}$ & $0.258^{*}$ & $0.548^{*}$ & $0.695^{*}$ & $0.031^{*}$ & $0.438^{*}$ & $0.943^{*}$ & 1.000 & & \\
\hline (8) $\ln I N F$ & $0.031^{*}$ & $0.140^{*}$ & $0.120^{*}$ & 0.306* & $0.169^{*}$ & $0.045^{*}$ & 0.038* & 1.000 & \\
\hline (9) $\ln U N E M$ & $0.142^{*}$ & $0.176^{*}$ & $0.211^{*}$ & -0.018 & $0.203^{*}$ & $0.120^{*}$ & $0.156^{*}$ & $0.053 *$ & 1.000 \\
\hline
\end{tabular}

Table 4 shows little association among the variables indicating a very low chance of endogeneity. Limited by the layout, only the correlation coefficient matrices and collinearity test results are provided here. However, the results meet the requirements of the correlation coefficient test and VIFs test. Also, the results show significance at at least a .10 level for all the variables. No variable shows association over a .90 level. 


\subsection{Econometric Models}

Multiple regression models have been run with the same dependent (FDI) and independent variables (gross domestic product, gross capital formation, value added of agriculture, fishing and foresty, value added of industry, import, export, inflation, unemployment). In the following section, the results of those models are presented and interpreted below.

Table 5. OLS Model

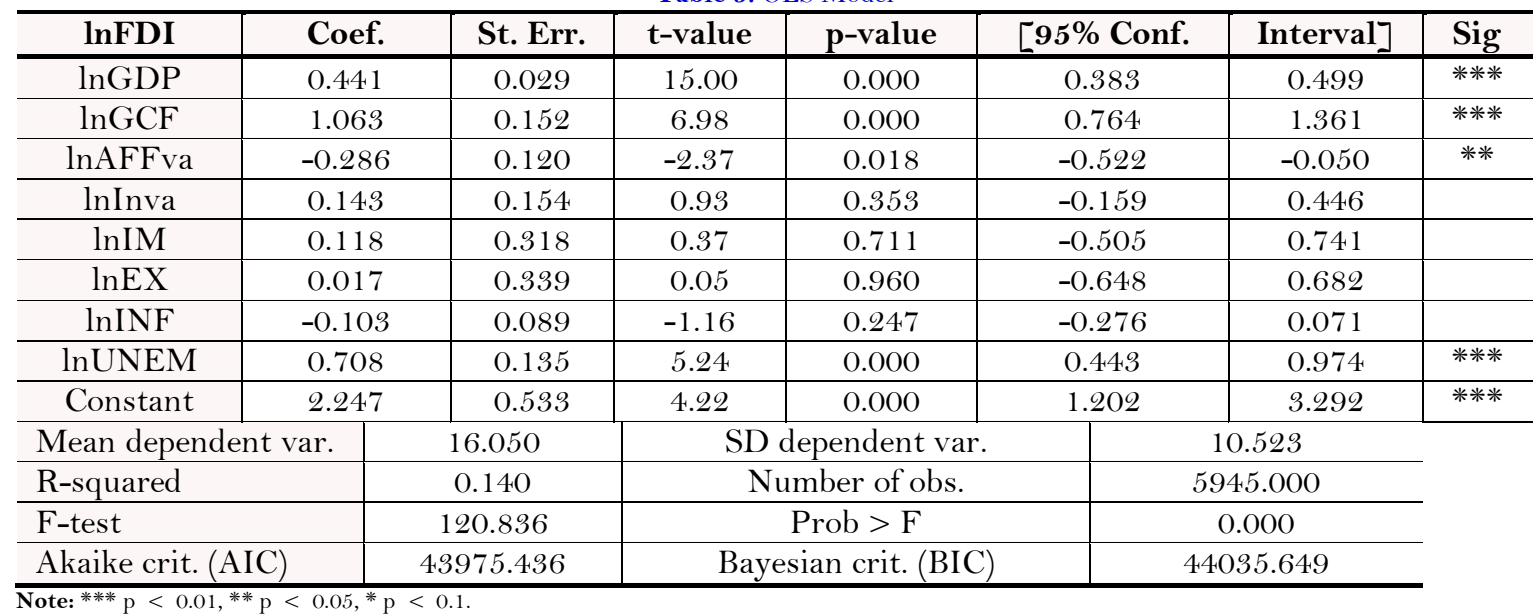

Table 5 shows the gross domestic product, gross capital formation, unemployment have significant positive and agriculture, forestry and fishing value added, and inflation have a significant negative relationship with FDI respectively. FDI is the reason for increasing GDP and GCF and due to an increase in FDI, sometimes agriculture, fishing and forestry of a country decrease. FDI sometimes causes decreasing inflation. On the contrary, other independent variables have a mixed but insignificant nature of the relationship with FDI though the overall model is significant at the $10 \%$ level. For more robustness of the results, the next model was run.

Table 6. Pooled OLS Model

\begin{tabular}{|c|c|c|c|c|c|c|c|}
\hline $\ln F D I$ & Coef. & St. Err. & t-value & p-value & $\begin{array}{l}{[95 \%} \\
\text { Conf. }\end{array}$ & Interval] & Sig \\
\hline $\ln G D P$ & 0.333 & 0.036 & 9.26 & 0.000 & 0.262 & 0.403 & **** \\
\hline $\ln \mathrm{GCF}$ & 0.684 & 0.205 & 3.35 & 0.001 & 0.283 & 1.085 & *** \\
\hline lnAFFva & -0.688 & 0.190 & -3.62 & 0.000 & -1.061 & -0.316 & $* * *$ \\
\hline lnInva & 0.555 & 0.180 & 3.08 & 0.002 & 0.202 & 0.909 & **** \\
\hline $\ln I M$ & 0.797 & 0.415 & 1.92 & 0.055 & -0.016 & 1.609 & $*$ \\
\hline $\ln \mathrm{EX}$ & -0.665 & 0.429 & -1.55 & 0.121 & -1.505 & 0.176 & \\
\hline $\ln I N F$ & -0.129 & 0.089 & -1.45 & 0.147 & -0.303 & 0.045 & \\
\hline $\ln \mathrm{UNEM}$ & 1.198 & 0.199 & 6.03 & 0.000 & 0.809 & 1.588 & **** \\
\hline Constant & 4.313 & 0.757 & 5.70 & 0.000 & 2.829 & 5.797 & **** \\
\hline \multicolumn{2}{|c|}{ Mean dependent var. } & 16.050 & \multicolumn{3}{|c|}{ SD dependent var. } & 10.523 & \\
\hline \multicolumn{2}{|c|}{ Overall r-squared } & 0.132 & \multicolumn{3}{|c|}{ Number of obs. } & 5945.000 & \\
\hline \multicolumn{2}{|c|}{ Chi-square } & 374.782 & \multicolumn{3}{|c|}{ Prob $>$ chi 2} & 0.000 & \\
\hline \multicolumn{2}{|c|}{ R-squared within } & 0.047 & \multicolumn{3}{|c|}{ R-squared between } & 0.315 & \\
\hline
\end{tabular}

Table 6 shows that gross domestic product, gross capital formation, import and unemployment have a significant positive relationship, and agriculture, forestry and fishing value added and inflation have a significant negative relationship with FDI. FDI is the reason for increasing gross domestic product, gross capital formation, import and unemployment, and due to an increase in FDI, sometimes agriculture, fishing and forestry of a country decrease. FDI sometimes causes a decrease in inflation. On the contrary, other independent variables have a mixed 
but insignificant relationship with FDI, though the overall model is significant at the 10\% level. For more robustness of the results, the next model was run.

Table 7. Driscoll-Kraay Pooled OLS Model.

Regression with Driscoll-Kraay standard errors; number of obs. = = = =

Method: Pooled OLS

Group variable (i): ID

Maximum lag: 3

\section{Number of groups}

$\mathrm{F}(8,28)$

Prob $>$ F

R-squared

Root MSE
$=$

$=$

$=$

$=$

$=$

$=$
5945

205

558.45

0.0000

0.1400

9.7652

\begin{tabular}{|c|c|c|c|c|c|c|}
\hline \multicolumn{7}{|c|}{ Driscoll-Kraay } \\
\hline $\operatorname{lnFDI}$ & Coef. & Std. Err. & t-value & $P>t$ & [95\%Conf. & Interval] \\
\hline $\operatorname{lnGDP}$ & 0.441 & 0.037 & 11.810 & 0.000 & 0.365 & 0.518 \\
\hline $\ln \mathrm{GCF}$ & 1.063 & 0.164 & 6.480 & 0.000 & 0.727 & 1.399 \\
\hline $\ln A F F_{v a}$ & -0.286 & 0.231 & -1.240 & 0.225 & -0.758 & 0.186 \\
\hline lnInva & 0.143 & 0.227 & 0.630 & 0.534 & -0.323 & 0.609 \\
\hline $\operatorname{lnIM}$ & 0.118 & 0.290 & 0.410 & 0.688 & -0.476 & 0.711 \\
\hline $\operatorname{lnEX}$ & 0.017 & 0.255 & 0.070 & 0.947 & -0.506 & 0.540 \\
\hline $\operatorname{lnINF}$ & -0.103 & 0.111 & -0.930 & 0.362 & -0.329 & 0.124 \\
\hline $\ln U N E M$ & 0.708 & 0.189 & 3.750 & 0.001 & 0.321 & 1.096 \\
\hline _cons & 2.247 & 0.540 & 4.160 & 0.000 & 1.140 & 3.354 \\
\hline
\end{tabular}

Table 7 shows that gross domestic product and gross capital formation have a significant positive relationship with FDI flow. The more foreign direct investment there is, the higher the gross domestic product and gross capital formation will be for those countries. Additionally, unemployment has a significant positive relationship with FDI. Other variables in this model are not significant because the probability of the t-value is more than $10 \%$. For more robustness of the results, the next model is presented.

Table 8. Two-stage Least Squares Model Instrumental Variables (2SLS) Regression.

\begin{tabular}{|c|c|c|c|c|c|c|c|}
\hline $\ln F D I$ & Coef. & St. Err. & $\begin{array}{c}\text { t- } \\
\text { value }\end{array}$ & p-value & {$[95 \%$ Conf } & Interval] & Sig \\
\hline $\ln G D P$ & 0.441 & 0.029 & 15.00 & 0.000 & 0.383 & 0.499 & **** \\
\hline $\ln A F F v a$ & -0.286 & 0.120 & -2.37 & 0.018 & -0.522 & -0.050 & *** \\
\hline lnInva & 0.143 & 0.154 & 0.93 & 0.353 & -0.159 & 0.446 & \\
\hline $\ln \mathrm{EX}$ & 0.017 & 0.339 & 0.05 & 0.960 & -0.648 & 0.682 & \\
\hline $\ln I N F$ & -0.103 & 0.089 & -1.16 & 0.247 & -0.276 & 0.071 & \\
\hline $\ln \mathrm{UNEM}$ & 0.708 & 0.135 & 5.24 & 0.000 & 0.443 & 0.974 & **** \\
\hline Constant & 2.247 & 0.533 & 4.22 & 0.000 & 1.202 & 3.292 & **** \\
\hline \multicolumn{2}{|c|}{ Mean dependent var. } & 16.050 & \multicolumn{3}{|c|}{ SD dependent var. } & \multicolumn{2}{|l|}{10.523} \\
\hline
\end{tabular}

Table 8 shows that gross domestic product and gross capital formation have a significant positive relationship with FDI flow. The more foreign direct investment, the higher the gross domestic product and gross capital formation for a country will be. On the contrary, other independent variables (agriculture, forestry and fishing, value added) have a significant negative relationship with FDI, though the overall model is significant at a .05 level. Besides these, unemployment has a significant positive relationship with foreign direct investment. For more robustness of the results, the next model was added. 
Asian Economic and Financial Review, 2021, 11(2): 129-140

Table 9. Generalized Method of Moments (GMM) Model.

\begin{tabular}{|c|c|c|c|c|c|c|c|}
\hline $\operatorname{lnFDI}$ & Coef. & St. Err. & t-value & p-value & [95\% Conf. & Interval] & Sig \\
\hline L.lnFDI & 0.149 & 0.041 & 3.65 & 0.000 & 0.069 & 0.229 & **** \\
\hline $\ln G D P$ & 0.395 & 0.065 & 6.13 & 0.000 & 0.269 & 0.522 & **** \\
\hline $\ln \mathrm{GCF}$ & 0.953 & 0.351 & 2.72 & 0.007 & 0.266 & 1.641 & **** \\
\hline lnAFFva & -0.359 & 0.232 & -1.55 & 0.122 & -0.813 & 0.096 & \\
\hline lnInva & 0.281 & 0.358 & 0.79 & 0.432 & -0.420 & 0.982 & \\
\hline $\operatorname{lnIM}$ & -0.754 & 0.538 & -1.40 & 0.161 & -1.809 & 0.300 & \\
\hline $\ln \mathrm{EX}$ & 0.717 & 0.535 & 1.34 & 0.180 & -0.332 & 1.767 & \\
\hline $\operatorname{lnINF}$ & 0.046 & 0.138 & 0.33 & 0.740 & -0.225 & 0.317 & \\
\hline $\operatorname{lnUNEM}$ & 0.397 & 0.330 & 1.20 & 0.229 & -0.250 & 1.044 & \\
\hline Constant & 2.600 & 1.284 & 2.03 & 0.043 & 0.084 & 5.116 & *** \\
\hline \multicolumn{2}{|c|}{ Mean dependent var. } & 16.221 & \multicolumn{2}{|c|}{ SD dependent var. } & \multicolumn{2}{|c|}{10.449} & \\
\hline \multicolumn{2}{|c|}{ Number of obs. } & 5740.000 & \multicolumn{2}{|c|}{ Chi-square } & \multicolumn{2}{|c|}{259.012} & \\
\hline
\end{tabular}

Table 9 shows that gross domestic product and gross capital formation have a significant positive relationship with FDI flow. The more foreign direct investment, the higher the gross domestic product and gross capital formation for a country will be. On the contrary, other independent variables have a mixed but insignificant relationship with FDI, though the overall model is significant at the .1 level.

Table 10. Generalized Method of Moments (GMM) Model (comparison of five models).

\begin{tabular}{|c|c|c|c|c|c|}
\hline & (1) & $(2)$ & (3) & $(4)$ & (5) \\
\hline & OLS & POLS & DK & 2SLS & GMM \\
\hline \multirow[t]{2}{*}{$\operatorname{lnGDP}$} & 0.441 *** & $0.333^{* * * *}$ & $0.4411^{* * *}$ & 0.441 *** & $0.395 * * *$ \\
\hline & (0.029) & (0.036) & (0.037) & (0.029) & $(0.065)$ \\
\hline \multirow[t]{2}{*}{$\ln \mathrm{GCF}$} & $1.063^{*} * *$ & $0.684^{*} * *$ & $1.063^{*} * *$ & $1.063 * * *$ & $0.953 * * *$ \\
\hline & $(0.152)$ & $(0.205)$ & $(0.164)$ & $(0.152)$ & $(0.351)$ \\
\hline \multirow[t]{2}{*}{ lnAFFva } & $-0.286 * *$ & $-0.688^{*} * *$ & -0.286 & $-0.286^{* *}$ & -0.359 \\
\hline & $(0.120)$ & $(0.190)$ & $(0.231)$ & (0.120) & $(0.232)$ \\
\hline \multirow[t]{2}{*}{ lnInva } & 0.143 & $0.555^{* * * *}$ & 0.143 & 0.143 & 0.281 \\
\hline & $(0.154)$ & $(0.180)$ & $(0.227)$ & $(0.154)$ & $(0.358)$ \\
\hline \multirow[t]{2}{*}{$\ln I M$} & 0.118 & $0.797^{*}$ & 0.118 & 0.118 & -0.754 \\
\hline & $(0.318)$ & $(0.415)$ & $(0.290)$ & $(0.318)$ & $(0.538)$ \\
\hline \multirow[t]{2}{*}{$\ln \mathrm{EX}$} & 0.017 & -0.665 & 0.017 & 0.017 & 0.717 \\
\hline & $(0.339)$ & $(0.429)$ & $(0.255)$ & $(0.339)$ & $(0.535)$ \\
\hline \multirow[t]{2}{*}{$\operatorname{lnINF}$} & -0.103 & -0.129 & -0.103 & -0.103 & 0.046 \\
\hline & $(0.089)$ & $(0.089)$ & $(0.111)$ & $(0.089)$ & $(0.138)$ \\
\hline \multirow[t]{2}{*}{$\operatorname{lnUNEM}$} & $0.708^{*} * * *$ & $1.198^{*} * *$ & $0.708 * * *$ & $0.708 * * *$ & 0.397 \\
\hline & $(0.135)$ & $(0.199)$ & $(0.189)$ & $(0.135)$ & $(0.330)$ \\
\hline \multirow[t]{2}{*}{ L.lnFDI } & & & & & 0. $149^{* * *}$ \\
\hline & & & & & $(0.041)$ \\
\hline \multirow[t]{2}{*}{ _cons } & $2.247^{*} * * *$ & $4.313 * * *$ & $2.247^{*} * *$ & $2.247 * * *$ & $2.600^{*} *$ \\
\hline & $(0.533)$ & $(0.757)$ & $(0.540)$ & $(0.533)$ & $(1.284)$ \\
\hline Obs. & 5945 & 5945 & 5945 & 5945 & 5740 \\
\hline
\end{tabular}

Table 10 shows that gross domestic product and gross capital formation have a significant positive relationship with foreign direct investment in all models. The more foreign direct investment, the more the gross domestic product and gross capital formation will be for a country. Agriculture, forestry and fishing value added has a significant negative relationship with foreign direct investment in the ordinary least squares, pooled ordinary least squares and two-stage least squares models. Industry (including construction) value added has a significant positive relationship with foreign direct investment in the pooled ordinary least squares model. Import also has a significant positive relationship with foreign direct investment in the pooled ordinary least square model. Export and inflation 
have no significant relationship with foreign direct investment, and unemployment has a significant positive relationship with foreign direct investment in all models except the GMM model.

\subsection{Hypothesis Results and Interpretation}

Based on the findings of the study, only two hypotheses proved to be right and supported by all regression models. In this study, gross domestic product and gross capital formation have a significant positive relationship with FDI flow. The more the foreign direct investment flow in the country, the more the gross domestic product and gross capital formation of that country will be. On the contrary, agriculture, forestry and fishing value added has a significant negative relationship with foreign direct investment in the ordinary least squares, pooled ordinary least squares and two-stage least squares models. Furthermore, unemployment has a significant positive relationship with foreign direct investment in the ordinary least squares, pooled ordinary least squares and twostage least squares models.

A summary of the results and interpretations of the hypotheses in this study have been presented in Table 11. Whether the null hypotheses have been accepted or rejected by all the models has also been reported.

Table 11. Hypotheses Test Results.

\begin{tabular}{|c|c|c|}
\hline No. & Hypothesis & Results \\
\hline $\mathrm{H}_{1}$ & $\begin{array}{l}\text { There is a significant positive relationship } \\
\text { between foreign direct investment and } \\
\text { gross domestic product. }\end{array}$ & $\begin{array}{l}\text { The result is positive and significant }(\mathrm{p}>\mathrm{OOO}) \text { and } \\
\text { is supported by the OLS, POLS, DK, 2SLS and } \\
\text { GMM models. } \\
\text { Note: the null hypothesis is rejected. }\end{array}$ \\
\hline $\mathrm{H}_{2}$ & $\begin{array}{l}\text { There is a significant positive relationship } \\
\text { between foreign direct investment and } \\
\text { gross capital formation. }\end{array}$ & $\begin{array}{l}\text { The result is positive and significant }(\mathrm{p}>\mathrm{OOO}) \text { and } \\
\text { is supported by the OLS, POLS, DK, } 2 \mathrm{SLS} \text { and } \\
\text { GMM models. } \\
\text { Note: the null hypothesis is rejected. }\end{array}$ \\
\hline $\mathrm{H}_{3}$ & $\begin{array}{l}\text { There is a significant positive relationship } \\
\text { between foreign direct investment and } \\
\text { agriculture, forestry and fishing, value } \\
\text { added. }\end{array}$ & $\begin{array}{l}\text { The result is negative but significant }(\mathrm{p}>000) \text { and } \\
\text { is supported by the OLS, POLS, DK and 2SLS } \\
\text { models. } \\
\text { Note: the null hypothesis is rejected. }\end{array}$ \\
\hline $\mathrm{H}_{4}$ & $\begin{array}{l}\text { There is a significant positive relationship } \\
\text { between foreign direct investment and } \\
\text { industry, value added. }\end{array}$ & $\begin{array}{l}\text { The result is positive and significant }(\mathrm{p}>000) \text { and } \\
\text { is supported by the POLS model. } \\
\text { Note: the null hypothesis is rejected. }\end{array}$ \\
\hline $\mathrm{H}_{5}$ & $\begin{array}{l}\text { There is a significant negative } \\
\text { relationship between foreign direct } \\
\text { investment and import of goods and } \\
\text { services. }\end{array}$ & $\begin{array}{l}\text { The result is positive and significant }(\mathrm{p}>000) \text { and } \\
\text { is supported by the POLS model. } \\
\text { Note: the null hypothesis is rejected. }\end{array}$ \\
\hline $\mathrm{H}_{6}$ & $\begin{array}{l}\text { There is a significant positive relationship } \\
\text { between foreign direct investment and } \\
\text { export of goods and services. }\end{array}$ & $\begin{array}{l}\text { The results are different and insignificant and not } \\
\text { supported by any of the five models. } \\
\text { Note: the null hypothesis is accepted. }\end{array}$ \\
\hline $\mathrm{H}_{7}$ & $\begin{array}{l}\text { There is a significant negative } \\
\text { relationship between foreign direct } \\
\text { investment and inflation, consumer prices. }\end{array}$ & $\begin{array}{l}\text { The results are different and insignificant and not } \\
\text { supported by any of the five models. } \\
\text { Note: the null hypothesis is accepted. }\end{array}$ \\
\hline $\mathrm{H}_{8}$ & $\begin{array}{l}\text { There is a significant negative } \\
\text { relationship between foreign direct } \\
\text { investment and the unemployment rate. }\end{array}$ & $\begin{array}{l}\text { The result is positive and significant }(\mathrm{p}>000) \text { and is } \\
\text { supported by the OLS, POLS, DK and 2SLS } \\
\text { models. } \\
\text { Note: the null hypothesis is rejected. }\end{array}$ \\
\hline
\end{tabular}

\section{CONCLUSION}

Based on the findings of the study, it can be recommended that for the growth of gross domestic product and gross capital formation, more foreign direct investment should be encouraged. Though foreign direct investment has a negative relationship with agriculture, forestry and fishing value added, FDI is badly needed for the growth of the industry of a country. Overall, the study of 205 countries over 29 years of dynamic panel data has produced 
valuable findings to help us understand the economies of the world regarding FDI and some macroeconomic variables.

\subsection{Contribution of the Paper}

The broad finding is that FDI does not necessarily enhance GDP every aspect except for the value added of agriculture, forestry and fishing. Specifically, this paper has mainly contributed in two aspects: first, it has predicted and shown the relationship of FDI with some macroeconomic variables across the countries of the world, and second, it has scrutinized and identified the impact of different macroeconomic variables on FDI flow through robust models, such as DK, $2 \mathrm{SLS}$ and GMM.

\subsection{Limitations and Further Research Opportunities}

Data were not collected for all the countries of the world because of the availability in the database. Also, more than 29 years' worth of data would have been more conclusive. Data had to be converted for analysis, which may have led to discrepancies. Also, many variables have remained uninvestigated by this research. Future studies may be conducted to discover the most important determinants of FDI besides the macroeconomic variables in this study.

Funding: This study received no specific financial support.

Competing Interests: The authors declare that they have no competing interests.

Acknowledgement: All authors contributed equally to the conception and design of the study.

\section{REFERENCES}

Aggarwal, A. (2002). Liberalisation, multinational enterprises and export performance: Evidence from Indian manufacturing. Journal of Development Studies, 38(3), 119-137. doi: https://doi.org/10.1080/00220380412331322371

Alfaro, L., Chanda, A., Kalemli-Ozcan, S., \& Sayek, S. (2004). FDI and economic growth: The role of local financial markets. Journal of International Economics, 64(1), 89-1 12. doi: https://doi.org/10.1016/s0022-1996(03)0008 1-3

Alguacil, M., Cuadros, A., \& Orts, V. (2011). Inward FDI and growth: The role of macroeconomic and institutional environment. Journal of Policy Modeling, 33(3), 481-496. doi: https://doi.org/10.1016/j.jpolmod.2010.12.004

Athukorala, P., \& Menon, J. (1995). Developing with foreign investment: Malaysia. Australian Economic Revierw, 28(1), 9-22. doi: https://doi.org/10.1111/j.1467-8462.1995.tboo873.x

Babajide, A. A., \& Lawal, A. I. (2016). Macroeconomic behaviour and FDI inflows in Nigeria: An application of the ARDL model. British Journal of Economics, Finance and Management Sciences, 11(1), 84-107.

Banga, R. (2006). The export-diversifying impact of Japanese and US foreign direct investments in the Indian manufacturing sector. Journal of International Business Studies, 37(4), 558-568. doi: https://doi.org/10.1057/palgrave.jibs.8400207

Barry, F., \& Bradley, J. (1997). FDI and trade: The Irish host-country experience. The Economic Journal, 107(445), $1798-1811$. doi: https://doi.org/10.1111/j.1468-0297.1997.tboo083.x

Bekhet, H. A., \& Al-Smadi, R. W. (2015). Determinants of Jordanian foreign direct investment inflows: Bounds testing approach. Economic Modelling, 46, 27-35. doi: https://doi.org/10.1016/j.econmod.2014.12.027

Bevan, A. A., \& Estrin, S. (2000). The determinants of foreign direct investment in transition economies (pp. 1- 57). Discussion Paper No. 2638. Center for Economic Policy Research, London.

Billington, N. (1999). The location of foreign direct investment: An empirical analysis. Applied Economics, 31(1), 65-76. doi: https://doi.org/10.1080/000368499324561

Blomstrom, M., Lipsey, R. E., \& Zejan, M. (1994). What explains developing country growth? (pp. 1-36). Washington DC: Institute of International Economics Press.

Boateng, A., Hua, X., Nisar, S., \& Wu, J. (2015). Examining the determinants of inward FDI: Evidence from Norway. Economic Modelling, 47, 118-127. doi: https://doi.org/10.1016/j.econmod.2015.02.018 
Borensztein, E., De Gregorio, J., \& Lee, J.-W. (1998). How does foreign direct investment affect economic growth? Journal of International Economics, 45(1), 115-135. doi: https://doi.org/10.1016/s0022-1996(97)00033-0

Carkovic, M., \& Levine, R. (2002). Does foreign direct investment accelerate economic growth? (pp. 195-22 1). Washington DC: Institute of International Economics Press.

De Mello, L. R. (1999). Foreign direct investment-led growth: Evidence from time series and panel data. Oxford Eeconomic Papers, 51(1), 133-151. doi: https://doi.org/10.1093/oep/51.1.133

Garibaldi, P., Mora, N., \& Sahay, R. (2002). What moves capital to transition economies? (pp. 1-47). Working Paper No. 02/64, International Monetary Fund, Washington, DC.

Iwasaki, I., \& Tokunaga, M. (2014). Macroeconomic impacts of FDI in transition economies: A meta-analysis. World Development, 61, 53-69. doi: https://doi.org/10.1016/j.worlddev.2014.03.022

James, B. A. (2008). Determinants of foreign direct investment in Malaysia. Journal of Policy Modeling, 30(1), 185-189. doi: https://doi.org/10.1016/j.jpolmod.2007.06.014

Kueh, J. S.-H., Puah, C.-H., \& Abu Mansor, S. (2009). Empirical analysis on emerging issues of Malaysia outward FDI from macroeconomic perspective. International Review of Business Research Papers, 5(4), 98-108.

Li, X., \& Liu, X. (2005). Foreign direct investment and economic growth: An increasingly endogenous relationship. World Development, 33(3), 393-407. doi: https://doi.org/10.1016/j.worlddev.2004.11.001

Markusen, J. R., \& Venables, A. J. (1999). Foreign direct investment as a catalyst for industrial development. European Economic Reviere, 43(2), 335-356.

Miankhel, A., Thangavelu, S., \& Kalirajan, K. (2009). Foreign direct investment. export and economic growth in selected emerging countries: Multivariate VAR analysis. MPRA Paper No. 22763.

Moran, T. H. (2012). The white house and the world : A global development Agenda for the Next U.S. President. In N. Birdsall (Ed.), Foreign direct investment and development (pp. 125-139).

Neuhaus, M. (2006). The impact of FDI on economic growth: An analysis for transnational countries of Central and Estern Europe (pp. 96). Heidelberg: Phisica.

Pradhan, R. P. (2010). Globalization in India: With special reference to the 1990s. Journal of Economics and International Finance, 2(5), $76-84$.

Reiter, S. L., \& Steensma, H. K. (2010). Human development and foreign direct investment in developing countries: The influence of FDI policy and corruption. World Development, 38(12), 1678-1691. doi: https://doi.org/10.1016/j.worlddev.2010.04.005

Schneider, F., \& Frey, B. S. (1985). Economic and political determinants of foreign direct investment. World Development, 13(2), 161-175. doi: https://doi.org/10.1016/0305-750x(85)90002-6

Sharma, K. (2000). Export growth in India- has FDI played a role? Yale University Discussion Paper No. 816.

Shiva, S. M., \& Agapi, S. (2008). Impact of foreign direct investment and trade on economic growth: Evidence from developing countries. American Journal of Agricultural Economics, 86(3), 795-801. doi: https://doi.org/10.1111/j.00029092.2004.00627.x

Sun, H. (2001). Foreign direct investment and regional export performance in China. Journal of Regional Science, 41(2), $317-336$. doi: https://doi.org/10.1111/0022-4146.00219

Tolentino, P. E. (2010). Home country macroeconomic factors and outward FDI of China and India. Journal of International Management, 16(2), 102-120.

Zhang, K. H., \& Song, S. (2001). Promoting exports: The role of inward FDI in China. China Economic Review, 11 (4), 385-396. doi: https://doi.org/10.1016/s1043-951x(01)00033-5

Zhang, K. H. (2005). How does FDI affect a host country's export performance? The case of China. Paper presented at the International Conference of WTO, China and the Asian Economies. 
Asian Economic and Financial Review, 2021, 11(2): 129-140 